\title{
Harmful effects of water pollution on some physiological responses of the Nile tilapia (Oreochromis niloticus) in both Qarun and Burullus Lakes \\ ${ }^{1}$ Eman, G.E. Helal; ${ }^{2}$ Abd El-Atti, M. S. and ${ }^{3}$ Yasmina, M.Ekraim \\ ${ }_{1,3}$ Zoology Department, Faculty of science (Girls), Al-Azhar University, Cairo Egypt \\ ${ }^{2}$ Zoology Department, Faculty of Science, Zagazig University, Egypt \\ Corresponding author: Eman Helal, email: emanhelal@ hotmail.com, Mobile: 00201001025364,orcid.org/0000-0003-0527-7028
}

\begin{abstract}
Background: Qarun and Burullus Lakes suffer from serious pollution problems owing to the enormous input of untreated agricultural, domestic and industrial effluents. This study was conducted to explain the effect of water pollution of these lakes on some physiological parameters of $O$. niloticus. Results: Showed clearly that water collected from both Qarun and Burullus Lakes were contaminated with high levels of lead and cadmium. The concentration of $\mathrm{Pb}$ and $\mathrm{Cd}$ in Lake Qarun (0.074 and 0.006 ppm respectively) were much lower than that of Burullus Lake (0.112 and $0.011 \mathrm{ppm}$ respectively). The study showed that the rates of $\mathrm{Pb}$ bioaccumulations were increased significantly in the muscles of $O$. niloticus collected from Brurllues Lake than that of Qarun Lake. It can be seen also that there are insignificant differences of Cd concentrations in muscles of tilapians collected from both Lakes. Analysis of liver functions shwoed a highly significant increase in the level of ALT in O. niloticus liver collected from Brurllues Lake than tilapia'sb liver from Qarun Lake. Both AST and GGT levels were insignificantly changed in fishes collected from both Lakes (no change in the table). Investigation of kidney functions of tilapias collected from Qarun and Burullus Lakes showed that urea concentration was significantly increased in kidney of Tilapia gathered from Burullus Lake $(32.40 \pm 0.93 \mathrm{mg} / \mathrm{dl})$ than those collected from Qarun Lake $(28.80 \pm 0.73 \mathrm{mg} / \mathrm{dl})$. Creatinine concentrations were significantly increased in kidney of tilapias gathered from Burullus Lake than Qarun Lake. Cholesterol, Triglycerides, high density lipoproteins (HDL), low density lipoproteins (LDL), and very low density lipoproteins (VLDL) in the muscles of tilapians collected from Burllues Lake were highly significant increase while total proteins were significantly decreased in comparison with tilapians of Qaron Lake.
\end{abstract}

Key words: Oreochromis niloticus - Physiology- Qarun and Burullus Lakes -Water pollution.

\section{INTRODUCTION}

Qarun Lake is found at the lowest part of El-Faiyoum depression. Although this Lake designated as protected area since 1989, it has hardly been protected from various polluting elements and suffers from serious pollution problems due to uncontrolled solid and liquid domestic and industrial waste disposal practice ${ }^{(1)}$. Burullus Lake is a brackish water Lake in the Nile Delta in Egypt and located in Kafr El-Sheikh Governorate. Burullus Lake is the second largest Lake along the Mediterranean Sea and represents one of the most subjected Lakes to pollution at the delta's coastline. This Lake serves as reservoirs for drainage waters, which are contaminated, with anthropogenic materials ${ }^{(2)}$.

Heavy metals are commonly found in natural waters and some are essential to living organisms, yet they may become highly toxic when present in high concentrations ${ }^{(3)}$. Aquatic organisms take up metals from water and their diet. Recent evidence suggests that dietary metal exposure is the predominant source for metal accumulation in some aquatic organisms ${ }^{(4)}$. Cadmium (Cd) has been considered as one of the most toxic heavy metals in the environment. $\mathrm{Cd}$ coexists with zinc in the zinc ore in nature. Weathering of rock is the major natural source of $\mathrm{Cd}$ in the environment. Industrial and agricultural activities such as mining, smelting and ore refining, electroplating processes, applications of fertilizers and pesticides contribute to Cd pollution in environment ${ }^{(5)}$. Cadmium binds strongly to organic matter where it is immobilized in soil and taken up by agricultural crops. A long-lasting exposure to lead and cadmium may cause changes in the immune response ${ }^{(6)}$.

Lead exposure is a global issue since lead mining and smelting, and battery manufacturing/disposal/recycling, are common in many countries. Lead enters the body via inhalation, ingestion, or skin absorption. Almost all inhaled lead is absorbed into the body; for ingestion, the rate is $20-70 \%$, with children absorbing a higher percentage than adults ${ }^{(7)}$. Acute exposures often manifest as central nervous system (CNS) and gastrointestinal symptoms. Pb targets the proximal tubules of the kidneys and is capable of inducing nephrotoxicity ${ }^{(8)}$.

Usage of biomarkers has become a valuable tool during monitoring the environmental quality and the health of fish inhabiting polluted ecosystems ${ }^{(9)}$. At present, the direct immunotoxicity of heavy metals is the subject of extensive studies, especially on in vitro models like fishes.

Therefore, this research was carried out to measure the levels of $\mathrm{Cd}$ and $\mathrm{Pb}$ in the water of both Qarun and Burullus Lakes and their bioaccumulation in the muscles of the Nile tilapia Oreochromis niloticus fish collected from the two 
Lakes, with investigating the effects of polluted water on some physiological and biochemical variables in this species.

\section{MATERIALS AND METHODS Study area}

The two investigated lakes are Qarun which is located about $80 \mathrm{~km}$ southwest of Cairo and Burullus lagoon which is located between the two Nile branches Rosetta to the west and Damietta to the east, Kafr El-Shiekh Governorate, Egypt.

\section{Water Sampling}

Surface water samples were collected about $20 \mathrm{~cm}$ below the water surface to avoid floating matter. Stoppered, acid-washed, polyethylene bottles were used as sampling devices. Water samples were filtered in the field using a polypropylene syringe fitted with a 0.45 $\mathrm{mm}$ Millipore cellulose acetate filter and acidified for preservation.

\section{Fish Sampling}

A total approximate number of fifty fish of Nile tilapia (O. niloticus) were randomly caught from the selected sites. All fish used were of uniform size $(16.5-17.5 \mathrm{~cm}$ and weight $95-99 \mathrm{~g})$ Fish were collected in closed meshed nets before being transferred in an ice box at $4^{\circ} \mathrm{C}$ until reach to the laboratory of Physiology, Zoology Department, Faculty of Science (Girls), Al-Azhar University. Thereafter, fishes were dissected to remove liver, kidney and muscle tissues.

Analysis of heavy metals in water and muscles of fish samples

All laboratory equipments and containers were washed with $10 \% \mathrm{HNO} 3$ solution prior to each use. Each sample (about 6 - 8 gm) was cut into small pieces, placed in Petri-dish and dried in hot air oven at $80^{\circ} \mathrm{C}$ until reaching a constant weight. Tissues were grinded to a powder and homogenized. One gram of each sample was weighed, transferred into screw caped glass bottled tube and $3 \mathrm{ml}$ of nitric acid high grade (68\%) was added to the sample. The mixture was left overnight at room temperature after tightly closing the tubes. Digestion was completed in a water bath at $60^{\circ} \mathrm{C}$ for about 1 hour until all the tissues were dissolved and the solution become clear, allowed to cool, filtered through What man (Ash less No. 42) filter paper, then transferred to $25 \mathrm{ml}$ volumetric flasks and made up to mark with deionized water. Metals analysis $(\mathrm{Pb}$ and $\mathrm{Cd})$ were measured in water and muscles by using Atomic

\section{Tissue preparation}

A known weight of each organ (liver and kidney) was homogenized in saline solution by using the electric homogenizer, for $2 \mathrm{~min}$. The homogenated specimens were centrifuged at 4000 r.p.m. for $15 \mathrm{~min}$. at $2 \mathrm{oC}$ in a refrigerator centrifuge. The supernatant solution was used or stored at -20 oC until the latter examinations.

\section{Biochemical analysis}

Concentrations of total proteins, total lipids, triglycerides, total cholesterol in muscles of O.niloticus were measured according to (Fernandez, 2009) ${ }^{(10)}$. Levels of HDL, LDL, VLDL, Creatinine, urea, Aspartate aminotransferase (AST), Alanine aminotransferase (ALT), and Gamma-Glutamyl transferase (GGT) activities were measured by using biome- rieux SA (France) Kit.

\section{Calculation of Bio-accumulation Factor (BAF)}

BAF for heavy metals in $O$. niloticus muscles were determined according to EPA guidelines. The BAF is defined as the ratio of chemical concentration in the organism to that in the surrounding water.

$\mathrm{BAF}$ was calculated as follows:

$\mathrm{BAF}=[\mathrm{Mt}] /[\mathrm{Mw}]$, where

$\mathrm{Mt}=$ Metal concentration in fish tissue $\mathrm{mg} / \mathrm{kg}$.

$\mathrm{Mw}=$ Metal concentration in water $\mathrm{mg} / \mathrm{l}$.

\section{Statistical analyses}

The statistical analysis was performed using SPSS 14.00. The mean values obtained in the different groups were compared by unpaired student's t-test.

\section{RESULTS}

Table (1) showed clearly that water collected from both Qarun and Burullus Lakes were contaminated with high levels of $\mathrm{Pb}$ and $\mathrm{Cd}$. The concentration of $\mathrm{Pb}$ and $\mathrm{Cd}$ in Lake Qarun were 0.074 and $0.006 \mathrm{ppm}$ respectively being much lower than that of Burullus Lake 0.112 and 0.011 respectively.

Table (1): Concentrations of $\mathrm{Pb}$ and $\mathrm{Cd}(\mathrm{ppm})$ in water samples collected from Qarun and Burullus Lakes.

\begin{tabular}{|l|c|c|}
\hline \multicolumn{1}{|c|}{ Parameters } & Qarun Lake & Burullus Lake \\
\hline Lead $(\mathrm{ppm})$ & 0.074 & 0.112 \\
\hline Cadmium $(\mathrm{ppm})$ & 0.006 & 0.011 \\
\hline
\end{tabular}

The data in table 2 showed that the rates of $\mathrm{Pb}$ bioaccumulations were increased significantly in the muscles of $O$. niloticus collected from 
Brurllues Lake $(0.99 \pm 0.03 \mathrm{ppm})$ than that of Qarun Lake $(0.40 \mathrm{ppm})$. It can be seen also that there were insignificant differences of $\mathrm{Cd}$ concentrations in muscle of $O$. niloticus collected from both lakes.

Table (2): The bioaccumulation of lead and cadmium $(\mathrm{ppm})$ bioaccumulation in muscles of Tilapia $(O$. niloticus) from Qarun and Burullus lakes

\begin{tabular}{|l|c|c|c|}
\hline \multicolumn{1}{|c|}{ Parameters } & Qarun Lake & Burullus Lake & P value \\
\hline Lead (ppm) & $0.40 \pm 0.01$ & $0.99 \pm 0.03 * *$ & $<0.01$ \\
\hline Cadmium(ppm) & $0.40 \pm 0.04$ & $0.52 \pm 0.02$ & $<0.05$ \\
\hline
\end{tabular}

Table (3) shwoed a highly significant increase in the level of ALT $(\mathrm{p}<0.01)$ in $O$. niloticus liver collected from Brurllues Lake than Tilapia liver from Qarun Lake.The data illustrated that there were no significant differences between levels of AST and GGT in fishes collected from both Lakes $(\mathrm{p}<0.05)$.

Table (3): Enzymatic activities of ALT, AST and GGT of $O$. niloticus liver collected from Qarun and Burullus lakes.

\begin{tabular}{|l|c|c|c|}
\hline $\begin{array}{c}\text { Parameter } \\
\text { s }\end{array}$ & Qarun Lake & $\begin{array}{c}\text { Burullus } \\
\text { Lake }\end{array}$ & $\begin{array}{c}\text { P } \\
\text { value }\end{array}$ \\
\hline ALT (U/l) & $\begin{array}{c}35.20 \\
\pm .31 * *\end{array}$ & $45.80 \pm 2.18$ & $<0.01$ \\
\hline AST(U/l) & $58.60 \pm 2.23$ & $54.80 \pm 1.96$ & Insig. \\
\hline GGT(U/l) & $8.80 \pm 0.20$ & $8.80 \pm 0.58$ & Insig. \\
\hline
\end{tabular}

Table 4 showed the kidney function of Tilapia (O. niloticus) collected from Qarun and Burullus lakes. It can be seen that urea and Creatinine concentrations were significantly increased in kidney of Tilapia gathered from Burullus Lake than Qarun Lake.

Table (4): Concentration of Urea and Creatinine in the kidney of Tilapia (O. niloticus) collected from Qarun and Burullus lakes

\begin{tabular}{|l|c|c|c|}
\hline \multicolumn{1}{|c|}{ Parameters } & $\begin{array}{c}\text { Lake } \\
\text { Qarun }\end{array}$ & $\begin{array}{c}\text { Lake } \\
\text { Burullus }\end{array}$ & $\begin{array}{c}\text { P } \\
\text { value }\end{array}$ \\
\hline $\begin{array}{l}\text { Urea }(\mathrm{mg} / \mathrm{dl}) \\
\text { Creatinine } \\
\text { (mg/dl) }\end{array}$ & $28.80 \pm 0.73$ & $32.40 \pm 0.93 *$ & $<0.05$ \\
\hline
\end{tabular}

Levels of Cholesterol, Triglycerides, high density lipoproteins (HDL), low density lipoproteins (LDL), and very low density lipoproteins (VLDL) in the muscle of Tilapia collected from Burllues Lake were highly significant increase $(\mathrm{P}<0.01)$ in comparison with Tilapia of Qaron Lake while total proteins were significantly decreased in the muscle of Tilapia collected from Burllues Lake compared to those from Qaron Lake (table 5).
Table (5): Levels of Total proteins, Cholesterol, Triglycerides, HDL, LDL, and VLDL in muscles of $O$. niloticus collected from in Qarun and Burullus Lakes

\begin{tabular}{|l|l|l|l|}
\hline Parameters & Qarun Lake & Burullus Lake & P value \\
\hline T. Proteins $(\mathrm{mg} / \mathrm{dl})$ & $3.28 \pm 0.15$ & $2.34 \pm 0.10^{* *}$ & $<0.01$ \\
\hline Cholesterol $(\mathrm{mg} / \mathrm{dl})$ & $52.00 \pm 0.71$ & $81.00 \pm 1.30 * *$ & $<0.01$ \\
\hline Triglycerides $(\mathrm{mg} / \mathrm{dl})$ & $16.00 \pm 0.71$ & $76.80 \pm 2.42 * *$ & $<0.01$ \\
\hline HDL $(\mathrm{mg} / \mathrm{dl})$ & $13.40 \pm 0.24$ & $22.60 \pm 0.93 * *$ & $<0.01$ \\
\hline LDL $(\mathrm{mg} / \mathrm{dl})$ & $32.80 \pm 0.37$ & $43.00 \pm 0.55 * *$ & $<0.01$ \\
\hline VLDL $(\mathrm{mg} / \mathrm{dl})$ & $4.60 \pm 0.51$ & $13.40 \pm 0.40 * *$ & $<0.01$ \\
\hline
\end{tabular}

\section{DISCUSSION}

Lake ecosystems are, in particular, vulnerable to heavy metal pollution. Tilapia nilotica is one of the aquatic organisms affected by heavy metals ${ }^{(11)}$. Among aquatic pollutants, heavy metals are considered as critical contaminants due to their strong impact on the stability of aquatic bodies, bioaccumulation in living organisms, toxicity persistence and tendency to accumulate in water ${ }^{(12)}$. The present study showed clearly that water collected from both Qarun and Burullus Lakes were contaminated with high levels of $\mathrm{Pb}$ and $\mathrm{Cd}$. The concentration of $\mathrm{Pb}$ and $\mathrm{Cd}$ in Lake Qarun were much lower than that of Burullus Lake. Hussein et al. (2008) reported that Lake Qarun has elevated concentrations of phosphorous and nitrogen that are conducive to algal blooms which leads to affect the fish and animal life in the lake with the great dangerous impact on the human health. The present findings are matching with results given by Hereher et al. (2010) and El-Kafrawy et al. (2015) for Lake Burullus. One of the significant challenges in Burullus Lake is represented in fish productivity.

During the period 2000-2002, field studies in Lake Burullus showed that the diversity of fishes was decreased from 32 to 25 species as a direct effect of pollution ${ }^{(15)}$. The determination of heavy metals in the fish muscles are carried out because muscles are the edible part of fish ${ }^{(16)}$.

The present study showed also that the rates of $\mathrm{Pb}$ and $\mathrm{Cd}$ bioaccumulations were increased significantly in the muscle of $O$. niloticus collected from Burullues Lake than that of Qarun Lake. This may be related to the highest concentrations of Lead and Cadmium water of this lake or the high organic carbon content in sediment to the excess of discharged industrial waste water effluents, sewage and agriculture waters with fertilizers and pesticide used in agriculture and human activities ${ }^{(17)}$. This finding is in agreement with Has-Schon et al. (2006) who reported 
that $\mathrm{Cd}$ and $\mathrm{Pb}$ were determined in different tissues (muscles, gills, stomachs, intestines, livers, vertebral column and scales) of Tilapia nilotica and their concentrations were higher in fish scales and vertebral column than in the other parts of the fish. Young et al., (2015) revealed that tilapia could accumulate $\mathrm{Cd}$ in the gonads and the accumulated $\mathrm{Cd}$ caused negative effects on gonad development.

Analysis of liver functions in this study shwoed a highly significant increase in the levels of ALT, AST and GGT in tilabian liver collected from Burullues Lake than those from Qarun Lake. In the present study, the elevation of AST and ALT activities in the liver, kidney, muscles of Oreochromis niloticus, inhabiting Lake Burullus is relatively higher than that collected from Qarun Lake. Such elevation might reflect the early toxic effects of heavy metals on the hepatic enzyme activities. on the other hand, the opposite effects on hepatic AST and ALT activities might be due to the liver necrosis induced by toxicants. This finding is in agreement with Murat et al., (2006) who used the enzymes as biomarkers of environmental pollution and where $\mathrm{AChE}$ activity which is mainly affected by heavy metals and pesticides has been lowered. $\ddot{O}_{z g}$ ür and Ferit (2010) found that combined effects of metals caused an increase in ALT and AST activities and in levels of albumin, transferrin, ceruloplasmin, cortisol, glucose, and total protein, whereas they caused a decrease in cholesterol levels.

The kidney is known to play an important role in the detoxification and excretion of toxicants, and this explains the high levels of heavy metals in this organ and considered as an important target organ for heavy metals accumulation (21). The present study showed that urea and creatinine concentrations were significantly increased in kidney of tilapians gathered from Burullus Lake than Qarun Lake.

Levels of cholesterol, triglycerides, high density lipoproteins (HDL), low density lipoproteins (LDL), and very low density lipoproteins(VLDL) in the muscle of tilapia collected from Burullues Lake were significantly increased in comparison with Tilapia of Qarun Lake while total proteins were significantly decreased and this may be due to defensive mechnisms in the fish to overcome the degenerative effects of heavy metals toxicity present in the two lakes.These findinges are in accordance with (Khadiga,2002) (22) who illustrated the effect of environmental factors of ambient water to the physiology of the cichlid, Oreochromis niloticus at
Lake Maryût. They also detected functional damages of the heart and liver in polluted fish due to the elevated serum enzymes.

The influence of toxicant on total protein content of Burullus has been showed a decrease in protein content of muscles. This reduction of tissues total proteins could be attributed to several pathological processes including plasma dissolution, renal damage elimination in the urine and decreased liver protein synthesis. This assumption suggested by Salah EL-Deen et al. ${ }^{(23)}$. The decrease of total proteins and total lipids in the muscles of Mugil cephalus collected from Lake Qarun may be attributed to the toxic effects of pollutants dissolved in the higher amounts of agriculture drainage water and humic matter, despite in the presence of high concentrations of heavy metals. This may be attributed to the changes in water quality by the action of heavy metals, that may critically influence the growth rate and quality of fish ${ }^{(24)}$. Serologic data of carbohydrates, lipids and proteins metabolites drew attention to the adverse effects on liver, heart and kidney functions of industrial and municipal discharges into the fishhabitats. The present results indicated that the biochemical parameters in the investigated fish can be used as an indicator of water pollution and heavy-metal toxicity.

\section{REFERENCES}

1. Hussein H, Amer R, Gaballah A, Refaat $Y$ and Abdel-Wahab A (2008): Pollution Monitoring for Lake Qarun. Advances in Environmental Biology, 2 (2):70-80.

2. El-Zeiny A and El-Kafrawy H (2017): Assessment of water pollution induced by human activities in Burullus Lake using Landsat 8 operational land imager and GIS. The Egyptian Journal of Remote Sensing and Space Science, 20: 49-56.

3. Eneji IS (2010): Spatial and temporal variation in the heavy metals loading of River Benue in Makurdi Metropolitan Area. Int. J. Environ. Res., 12(4): 4128-4140.

4. Wang WX (2011): Incorporating exposure into aquatic toxicological studies: an imperative. Aquat. Toxico., 105:9-15

5. Zhang W.L Du Y Z and Shang, M.M. (2014): Cadmium exposure and its health effects: A19-year follow-up study of a polluted area in China. Sci. Total Environ., 14: 224-228. 
6. Skoczyńska A, Poreba R, Sieradzki, A, Andrzejak R, and Sieradzka U (2002): The impact of lead and cadmium on the immune system. US National Library of Medicine National Institutes of Health, 53(3): 259-264.

7. Lewis J (1985): "Lead Poisoning: A Historical Perspective". EPA Journal. United States Environmental Protection Agency, 11 (4): 15-18.

8. Deborah E, Keil J, Berger-Ritchie, Gwendolyn A and Mc Millin (2011): Testing for toxic elements: A focus on arsenic, cadmium, lead, and mercury. Laboratory Medicine, 42:735-742.

9. Ronvan O, Jonny B and Vermeulenc P (2003): Fish bioaccumulation and biomarkers in environmental risk assessment. Environmental Toxicology and Pharmacology, 13(2): 149- 157.

10. Fernandez AV, Almeida EA and Barea JL (2009): Biochemical and proteomic effects in Procambarusclarkii after chlorpyrifos or carbaryl exposure under sublethal conditions. Freshwater crayfish, 14(5): 299-310.

11. Rashed MN (2001): Cadmium and lead levels in Fish (Tilapia Nilotica) tissues as biological indicator for Lake Water pollution. Environmental Monitoring and Assessment, 68(1): 75-89.

12. Has-Schon E, Bogut I and Strelec I (2006): Heavy metal profile in five fish species included in human diet, domiciled in the end flow of River Neretva (Croatia). Arch. Environ. Contam. Toxicol., 50(4): 545-551.

13. Hereher M, Salem M and Darwish D (2010): Mapping water quality of Burullus Lagoon using remote sensing and geographic information system. J. Am. Sci., 7 (1): 138-143.

14. El-Kafrawy SB, Khalafallah A, Omar M, Khalil MM,Yehia A and Allam M (2015): An integrated field and remote sensing approach for water quality mapping of Lake Burullus, Egypt. Int. J. Environ. Sci. Eng., 6: 15-20.

15. El-Adawy A, Negm A M, Elzeir, M A, ElShinnawy I A and Nadaoka $K$ (2013): Modeling the hydrodynamics and salinity of El-Burullus Lake (Nile Delta, Northern Egypt). J. Clean Energy Technol., 1 (2):65-72.
16. EL-Shebly A A (2002): Seasonal variations of some biochemical parameters in muscles of Oreochromis niloticus, reared in Lake Manzalah fish farms. Bull. Nat. Inst. Oceanogr. andFish.A.R.E., 28:201-215.

17. Zyadah MA, Abdel-Baky TI and Khair ELDeen SS (2003): On the bioaccumulation of some heavy metals in two fishes from Damietta and Rosetta estuaries of the River Nile.Egypt.J.Aquat.Boil.andFish,7(2):51-70.

18. Young J, Huan Z, Zhou,W, Chen J, Xiao, F and Huang H (2015): Subchronic effects of cadmium on the gonads, expressions of steroid hormones and sex-related genes in tilapia Oreochromis niloticus. Ecotoxicology, 24(10):2213-2223.

19. Murat O, Abbas G, Zehra $K$ and Elif G (2006): Monitoring the effects of water pollution on Cyprinuscarpio in Karakaya Dam Lake, Turkey. Ecotoxicology, 15(2):157-169.

20. Özgür $F$ and Ferit $K$ (2010): Individual and combined effects of heavy metals on serum biochemistry of Nile tilapia, Oreochromis niloticus. Archives of Environmental Contamination and Toxicology,58(1): 151-157.

21. Bahnasawy M H (2001): Levels of heavy metabolism catfish, Clariasgariepinus, from different habitats and their effects on some biochemical parameters.Egypt.J.Aquat. Boil. andFish,5(1):99-125.

22. Khadiga G, Adham HM, Ibrahim S, Hamed SR and Saleh A (2002): Blood chemistry of the Nile tilapia, Oreochromis niloticus (Linnaeus, 1757) under the impact of water pollution. Aquatic Ecology, 36(4): 549- 558.

23. Salah EL-DeenM A,Salah R E,Issa A M andAbo-Hegab $S$ (2000): Some metallic alterations in grass carp, Ctenopharyngodonidella, by exposure tomercury and zinc.Egypt. J. Aquat.Biol.and fish, 4(3):21-43.

24. Hodson P, Whittle DM, Wong PTS, Borgmann Thomas RH, Chan TK, Nriagu LD and Hullett DJ (1984): Toxic contaminants in the great Lakes. Niragh and Simmone (eds): John Wiley and Sons, New York.pp.333-340. 